\title{
Combining regional to local restoration goals in the Brazilian Atlantic forest
}

\author{
Cassia M.G. Lemos ${ }^{1}$ (D) - Pedro R. Andrade ${ }^{1} \cdot$ Ricardo R. Rodrigues $^{2} \cdot$ Leticia Hissa $^{3}$ • Ana P. D. Aguiar ${ }^{1,4}$
}

Received: 23 December 2020 / Accepted: 17 May 2021 / Published online: 15 June 2021

(C) The Author(s) 2021

\begin{abstract}
To achieve regional and international large-scale restoration goals with minimum costs, several restoration commitments rely on natural regeneration, a passive and inexpensive strategy. However, natural regeneration potential may vary within the landscape, mainly due to its historical context. In this work, we use spatially explicit restoration scenarios to explore how and where, within a given region, multiple restoration commitments could be combined to achieve cost-effectiveness outcomes. Our goal is to facilitate the elaboration of forest restoration plans at the regional level, taking into consideration the costs for active and passive restoration methods. The approach includes (1) a statistical analysis to estimate the natural regeneration potential for a given area based on alternative sets of biophysical, land cover, and/or socioeconomic factors and (2) the use of a land change allocation model to explore the cost-effectiveness of combining multiple restoration commitments in a given area through alternative scenarios. We test our approach in a strategic region in the Brazilian Atlantic Forest Biome, the Paraiba Valley in São Paulo State. Using the available data for 2011, calibrated for 2015, we build alternative scenarios for allocating natural regeneration until 2025. Our models indicate that the natural regeneration potential of the region is actually very low, and the cost-effectiveness outcomes are similar for all scenarios. We believe our approach can be used to support the regional-level decision-making about the implementation of multiple commitments aiming at the same target area. It can also be combined with other approaches for more refined analysis (e.g., optimization models).
\end{abstract}

Keywords Ecological forest restoration $\cdot$ Restoration methods $\cdot$ Cost-effectiveness $\cdot$ Land change models $\cdot$ Restoration planning $\cdot$ Payments for environmental services

\section{Introduction}

Forest restoration is crucial to reverse the impacts of historical deforestation, safeguarding biodiversity and an adequate provision of ecosystem services, including climate change

Communicated by Anna Cord

Cassia M.G. Lemos

cassia.lemos@inpe.br; cassia.mg.lemos@gmail.com

Pedro R. Andrade

pedro.andrade@inpe.br

Ricardo R. Rodrigues

rrresalq@usp.br

Leticia Hissa

leticiabvhissa@gmail.com mitigation, and adaptation (IPBES 2019). Given its importance, there are multiple ongoing restoration efforts at several scales. Taken together, countries have committed to restore a global area equivalent to the size of China (Sewell et al. 2020). Examples of restoration commitments are the Bonn Challenge

Ana P. D. Aguiar

ana.aguiar@inpe.br

1 Brazilian Institute of Space Research (INPE), São José dos Campos, SP 12227-010, Brazil

2 University of São Paulo, Piracicaba, SP 13418-900, Brazil

3 Center for Conservation and Sustainability, Smithsonian Institution, Washington, DC 20013, USA

4 Stockholm Resilience Center, Stockholm University, SE-114 19 Stockholm, Sweden 
and the New York Declaration that are worldwide efforts to restore 150 million hectares (Mha) of degraded and deforested lands by 2020 and 350 Mha by 2030, respectively (Lewis et al. 2019). Brazil voluntarily committed to restore $12 \mathrm{Mha}$ of forests by 2030 for multiple uses, as part of its Nationally Determined Contribution (NDC) to the United Nations Framework Convention on Climate Change (UNFCCC) as well as it is one of the goals of the Brazil's National Plan for Native Vegetation Recovery (Brancalion et al. 2019). Moreover, the Atlantic Forest Restoration Pact, a multistakeholder coalition, aims to restore 15 Mha of degraded lands in the Brazilian Atlantic Forest Biome by 2050 (Calmon et al. 2011). The Pact pledged to contribute with 1 Mha to the 2020 Bonn Challenge. From those, around 700,000 ha has been achieved from 2011 to 2015 (Crouzeilles et al. 2019).

Planning the necessary change in land systems to accommodate restoration projects is always complex and challenging due to the varied interests of decision-makers acting on the landscape (Boillat et al. 2017). Previous studies emphasize the relevance of adopting a multiscale approach to achieve effective large-scale restoration planning (Adams et al. 2016). Frequently, reaching tropical forest landscape restoration goals is proposed through passive ecological restoration as it is a cheaper strategy and easier to be implemented (Crouzeilles et al. 2020). In situations of historical anthropogenic degradation, passive ecological restoration methods need to be combined with active ones to achieve better outcomes (Rodrigues et al. 2011), considerably increasing the cost of the restoration. For example, restoration costs may range from US\$ 50.03 to US\$2102.83 per hectare in the Brazilian Atlantic Forest depending on the ecological restoration method adopted (Brancalion et al. 2019).

Assessing the potential for employing passive restoration methods in a given area is therefore essential for planning such large-scale ecological forest restoration commitments (Brancalion et al. 2019). The potential is dependent on natural ecological succession processes. It relies on favorable biophysical conditions for native seedling establishment and growth, the spontaneous arrival of new species over time, and presence of species with differing and complementary ecological behaviors (Rodrigues et al. 2011). For example, shrubs and herbaceous plant species in parts of the Loess Plateau in China present different potentially suitable habitats, but both need to be considered the pioneer plants of revegetation in future revegetation plans (Zheng et al. 2021). In general, one challenge for employing passive restoration methods is the difficulty to reliably predict the future species composition (Vickers et al. 2011). In the Brazilian Atlantic Forest, previous studies have estimated the natural regeneration potential using empirical analysis based on multiple biophysical, land use history, and socioeconomic factors (Silva et al. 2016a; Molin et al. 2018; Strassburg et al. 2018; Carvalho
Ribeiro et al. 2020), without differentiating, in most cases, the factors influencing the ecological regeneration process from the socioeconomic context.

In this work, we build upon these previous studies to propose a novel spatially explicit scenario approach to explore how and where, within a given region, multiple restoration commitments could (a) be implemented through natural regeneration and (b) be combined to achieve cost-effectiveness outcomes in order to gain scale. Our goal is to facilitate the elaboration of forest restoration plans at the regional level, taking into consideration the costs for active and passive restoration methods. The approach includes (1) a statistical analysis to estimate the natural regeneration potential for a given area based on alternative sets of biophysical, land cover, and/ or socioeconomic factors and (2) the use of a land change allocation model to explore the cost-effectiveness of combining multiple restoration commitment through alternative scenarios representing different restoration commitments in our study area. We test our approach in a strategic region in the Brazilian Atlantic Forest Biome, the Paraiba Valley in São Paulo State.

This region is an old occupation area undergoing a forest transition process, and it is one of the strategic regions to the Brazilian economic development (Silva et al. 2016b). For this reason, it has been chosen as a target area for different programs for Payments for Environmental Services (PSA), such as the Protection PSA Program (SÃO PAULO 2017, 2019) and Hydric PSA Program (OIKOS 2015). The Protection PSA is a state-level program with the objective of financing remnant forest protection and restoration actions in rural private properties located in key areas for water and biodiversity conservation. The Hydric PSA Program is a local-level program implemented with the objective of restoring areas that are relevant to water security in the Paraiba Valley in São Paulo. Moreover, our study area, as an example of a degraded pasture area undergoing a forest transition process (Silva et al. 2016b) inside the Atlantic Forest biome, is also relevant for a largescale national level restoration commitment, the Atlantic Forest Restoration Pact. In this way, the Protection PSA Program, the Hydric PSA Program, and the Atlantic Forest Restoration Pact are three restoration commitments that we consider in this study. The three scenarios that we explore correspond to the alignment of these three commitments.

The goal of our scenarios is to analyze the costeffectiveness of combining the Atlantic Forest Restoration Pact to other programs targeting our study area. Using the allocation model of land use change, we compare the costs of restoration (combining passive and active methods) and gains (in biodiversity, carbon, and soil) of the alternative allocation scenarios aligned with the different restoration commitments. The scenarios explore the cost-effectiveness of maintaining a high rate of conversion from pasture to regenerated forest $\left(60 \mathrm{~km}^{2} /\right.$ year), according to the priority areas defined by 
different restoration programs in the region. We calibrate our models with empirical evidence of regeneration from 1985 to 2011, validate the model until 2015, and build alternative scenarios until 2025, as follows.

\section{Material and methods}

\section{Study area}

Our study area is of the Paraiba Valley located in São Paulo State (in Portuguese, Vale do Paraíba Paulista (VPP)) in the Southeast of Brazil (Fig. 1). This region occupies, approximately, 1.4 Mha, encompassing 34 administrative municipal units. Economically, it is one of the most developed regions in the country, with a flourishing industrial park along a major highway connecting São Paulo to Rio de Janeiro. Although the area is located in the Atlantic forest biome, it contains some patches of Cerrado and special vegetation classes, such as rock outcrop vegetation (IBGE 2012) (Fig. 1). By the reason of the different adaptation for biophysical conditions of each vegetation class (Scarano 2007; Rossato et al. 2009;
Mendes et al. 2019), and considering that Atlantic Forest vegetation is the most representative vegetation class in the study area, covering approximately $80 \%$ of the region, we focus our analysis solely on the area that has been originally occupied by Atlantic Forest vegetation.

\section{Land change process and data}

The study area has undergone historical different cycles of agricultural production since the nineteenth century, and lost most of its original forest areas in this process (Silva et al. 2017). However, from 1985 to 2015 , the areas covered by forest increased from 21 to $37 \%$, mostly converted from pasture that dropped from 69 to $47 \%$ (Silva et al. 2016b; Ronquim et al. 2016). Although there was some active ecological restoration, the forest cover increase is dominated by natural regeneration (Silva et al. 2017). Therefore, here we adopt the assumption that forest cover increase in the study area is $100 \%$ related to natural regeneration. We base our analysis on a land cover map series covering the 1985 to 2015 period (available for 1985, 1995, 2005, 2011, 2015), derived from remote sensing images by Silva et al. (2016b) and

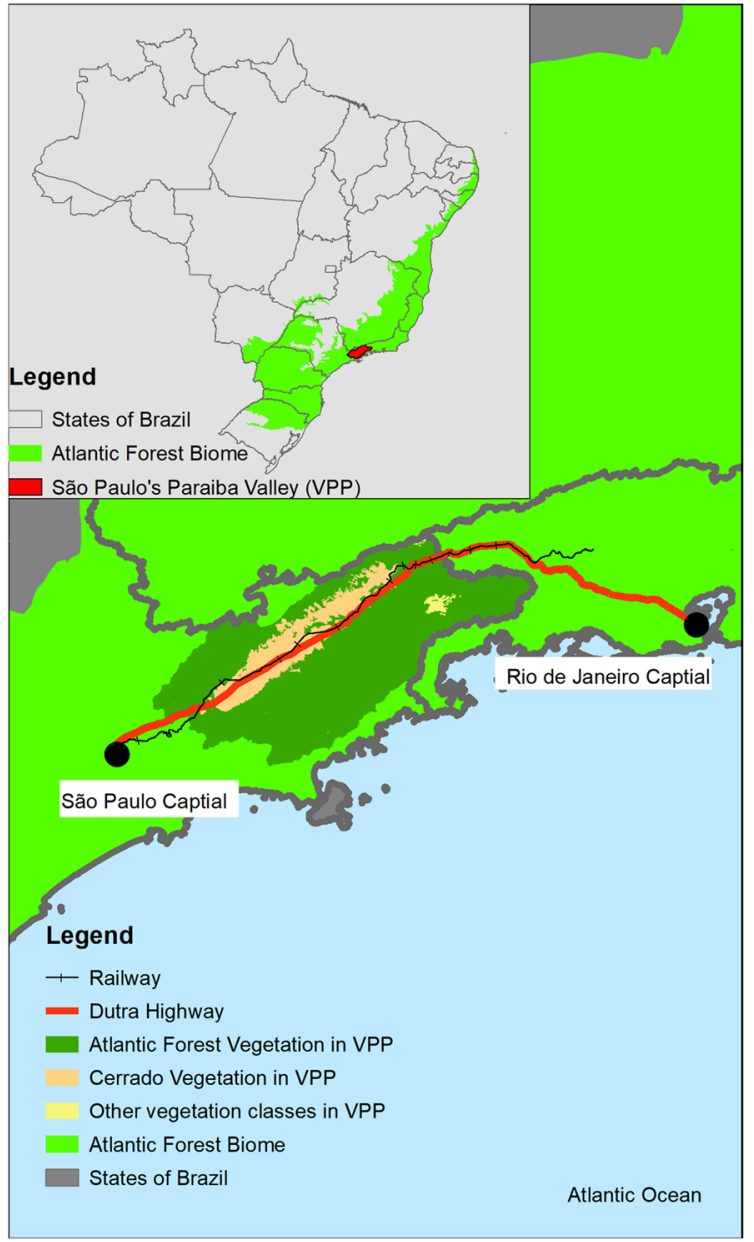

Fig. 1 Location of the study area
Land cover in 2015 in the Atlantic Forest in the São Paulo's Paraiba Valley

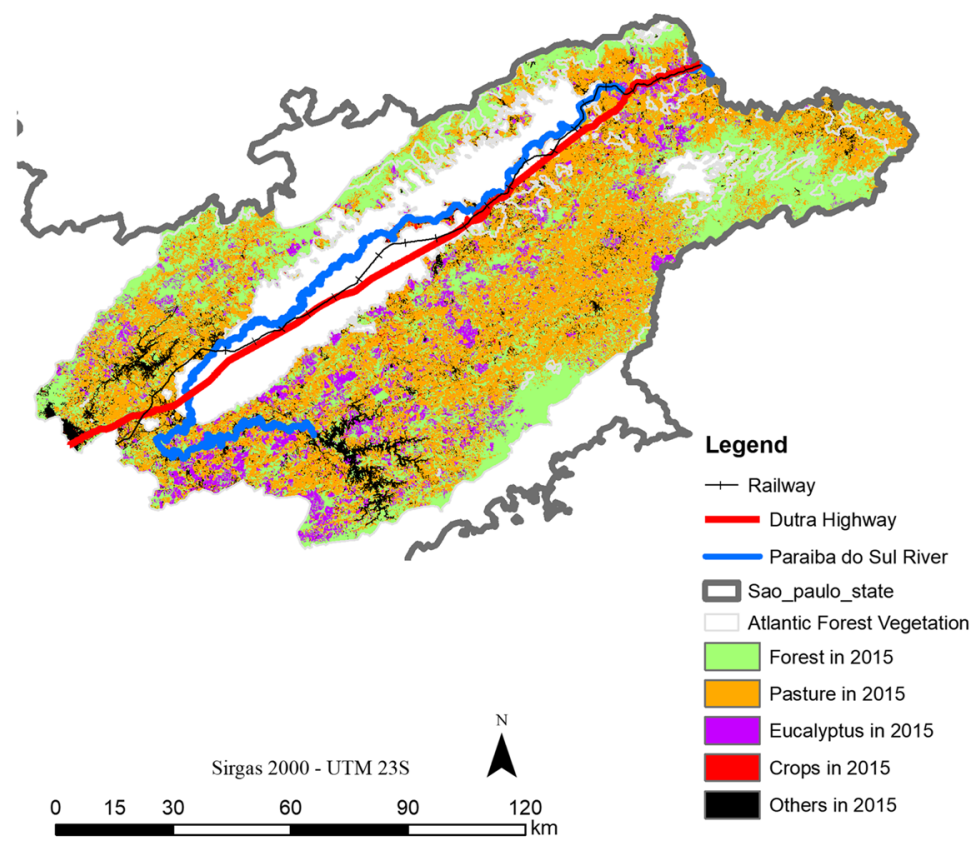


Ronquim et al. (2016). From a temporal analysis of these maps, we extract regenerated forest cover maps for 2011 and 2015, the calibration/validation period of our model, as discussed in the "LuccME modeling approach" section. When a forest area has been identified as non-forest by the land cover maps (Silva et al. 2016a; Ronquim et al. 2016) as non-forest in the previous years of the analysis, this area is reclassified as a regenerated forest. A similar approach of forest cover reclassification is applied in other studies (Schulz and Schroder 2017; Crouzeilles et al. 2020). When the forest area is classified as forest for all years of analysis, this area is reclassified as a remnant forest. Our main focus of interest in this work is the conversion from pasture cover to regenerated forest cover, as this is the dominant process in the region (Pandovezi et al. 2018). Pasture areas in the study area usually have low productivity, and thus reduced land competition for more profitable uses, which might favor natural regeneration (Strassburg et al. 2018). Table 1 summarizes the land cover change in the study area from 1985 to 2015 (Figs. 1 and SM.1 illustrate them).

\section{Cellular database organization}

In this work, we apply an empirical analysis to capture which biophysical and socioeconomic factors (the "Explanatory factors related to natural regeneration spatial patterns" section) relate to the regenerated forest cover in 2011. This empirical analysis is used to identify the relevant factors as well as their quantitative relationships with land cover changes. The first step in this analysis is to organize the multiple data sets in a comparable spatial and temporal resolution. In particular, considering the disparity of resolutions between the land cover data sources $(30 \mathrm{~m} \times 30 \mathrm{~m})$ and socioeconomic data derived from census data (in our case study, we have 34 municipalities in the area, with an average size of $410 \mathrm{~km}^{2}$, Table SM.1), we

Table 1 Summary of land cover in the study area from 1985 to 2015

\begin{tabular}{|c|c|c|c|c|c|}
\hline \multirow[t]{2}{*}{ Land cover } & \multicolumn{5}{|c|}{ Area $\left(\mathrm{km}^{2}\right)$ and $\%$} \\
\hline & 1985 & 1995 & 2005 & 2011 & 2015 \\
\hline Remnant forest & 2432 & 1959 & 1829 & 1771 & 1687 \\
\hline$\%$ & $21 \%$ & $17 \%$ & $16 \%$ & $15 \%$ & $14 \%$ \\
\hline Regenerated forest & n.a. & 1465 & 1978 & 2442 & 2639 \\
\hline$\%$ & - & $13 \%$ & $17 \%$ & $21 \%$ & $23 \%$ \\
\hline Pasture & 8083 & 7232 & 6856 & 6031 & 5453 \\
\hline$\%$ & $69 \%$ & $62 \%$ & $58 \%$ & $52 \%$ & $47 \%$ \\
\hline Other land covers & 1136 & 995 & 988 & 1407 & 1872 \\
\hline$\%$ & $10 \%$ & $8 \%$ & $9 \%$ & $12 \%$ & $16 \%$ \\
\hline Total & 11651 & 11651 & 11651 & 11651 & 11651 \\
\hline$\%$ & $100 \%$ & $100 \%$ & $100 \%$ & $100 \%$ & $100 \%$ \\
\hline
\end{tabular}

perform a preliminary analysis to verify which spatial resolution better aggregates the multiple data sources, capturing the general trends and relationships between land cover and the socioeconomic and biophysical factors. It is known from the literature that coarser resolutions tend to improve the capture of general patterns (Verburg et al. 1999; Aguiar et al. 2007).

In order not to lose information derived from the finer scale data sets, we use continuous variables to represent our land cover and biophysical variables, following the works of Verburg et al. (1999) and Aguiar et al. (2007). We characterize the land cover by the relative extent of each land cover class in each grid cell, e.g., a grid cell can contain $30 \%$ remnant forest, $40 \%$ pasture, and $30 \%$ regenerated forest. Based on this preliminary analysis, we organize our data as continuous variables in regular cells of $1 \mathrm{~km} \times 1 \mathrm{~km}$, using the TerraView/TerraME/LuccME environment (Carneiro et al. 2013). A regular grid of $1 \mathrm{~km}^{2}$ is used in Schulz and Schroder (2017) that has a study area with similar extension of our study.

Figure 2 illustrates the spatial distribution of percentage of remnant forest, regenerated forest, and pasture in the $1 \mathrm{~km} \times$ $1 \mathrm{~km}$ cells (in 2015). The histogram in Fig. SM.3 illustrates that cells have, in average, $20 \%$ of regenerated forests.

\section{Explanatory factors related to natural regeneration spatial patterns}

Previous studies investigate different combinations of historical land use, multiple socioeconomic and biophysical drivers to explain the natural regeneration in different countries, and the Atlantic Forest and/or VPP. Table 2 summarizes their findings, spatial and temporal scale, and methods used.

Based on these previous studies summarized in Table 2, we compile an initial set of twenty-four candidate variables that could potentially explain the natural forest regeneration process that took place in our study area from 1985 to 2011. These candidate variables are also organized into the cellular space (CS) of $1 \mathrm{~km} \times 1 \mathrm{~km}$. The CS allows us to homogenize different data sources and easily explore the statistical relationship with land change variables ("Land change process and data" section). The candidate variables correspond to the following broad categories (see details in Tables SM.2 and SM.3):

- Biophysical factors: We select a group of nine candidate variables which could capture the main drivers of the ecological processes underlying natural regeneration. In relation to terrain characteristics, we consider aspect, surface curvature, and slope. Each factor is categorized into a small number of classes and included in our database as percentage of each class (e.g., percentage of steep slope). Each cell also has a variable representing the average elevation. We include categories related to soil type and agricultural suitability, following Rossi (2017) and Pandovezi et al. (2018), 
Spatial distribution of land cover classes in 2015 in the cells of $1 \times 1 \mathrm{~km}^{2}$

a) remnant forests

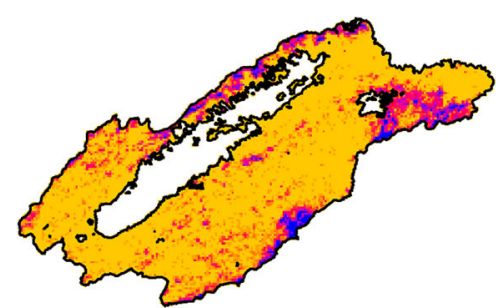

Legend of Percentage of land cover

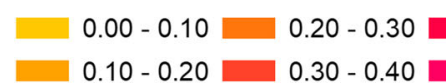

b) pasture
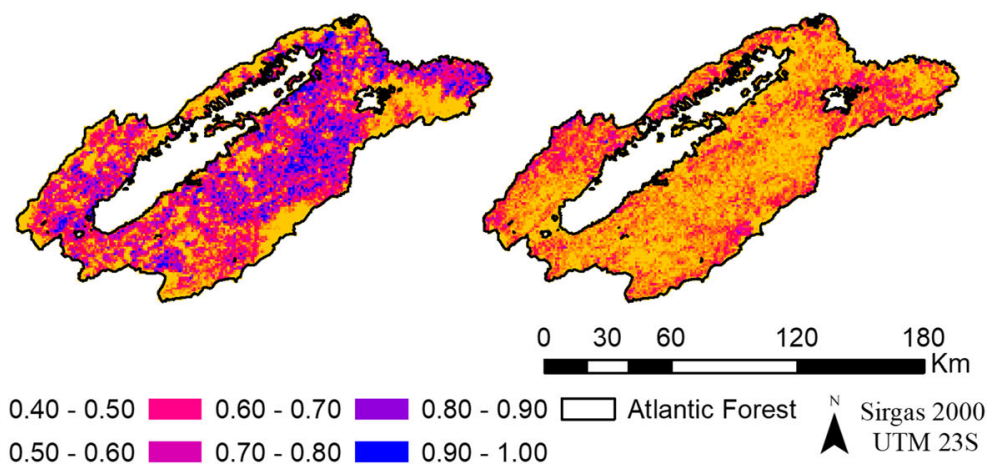

Fig. 2 Spatial distribution of land cover classes in 2015, aggregated as a percentage of $1 \mathrm{~km} \times 1 \mathrm{~km}$ cells: (a) remnant forests; (b) pasture; (c) regenerated forests

respectively. We have climate related factors, including temperature and precipitation, included as averages in the cells. Finally, related to water availability, we include the variable distance to the waterbody.

- Land cover factors: We include candidate variables related to proximity/percentage of forest, proximity/percentage of eucalyptus, and percentage of degraded pasture. Forest cover is chosen because several studies (Table 2) concluded that proximity to forest areas is one of the main drivers for natural regeneration. Silva et al. (2016a) identify a trend of forest cover increase near eucalyptus plantations in the VPP. Finally, degraded pasture is chosen because it is the land use class that has contributed over $70 \%$ to the new forest cover areas on VPP (Silva et al. 2016a). These historical land use variables are important to represent the dynamics of land change conversion that contribute to forest cover increase in VPP.

- Socioeconomic factors: We include variables broadly related to accessibility, relevant socioeconomic activities in the area, and rural/urban relations. Accessibility factors include distance to dutra highway (one of the most important highways in Brazil, with a large concentration of industries and population) and distance to urban centers. Previous studies use these variables (Silva et al. 2016a; Crouzeilles et al. 2020) to represent accessibility and to identify marginal lands, more likely to be set aside for natural regeneration (Molin et al. 2018). We select three indicators representing the main rural activities developed in pasturelands of our study area, namely stocking rate, milk productivity, and milk revenue. Besides, similar to Silva et al. 2016b, we include indicators of rural population, farm jobs, farm revenue, farm profit, and farm credit. These socioeconomics variables are important to represent the rural conditions in relation to the total socioeconomic conditions in the municipalities (Silva et al. 2016a).

\section{Exploratory analysis and selection of alternative statistical models}

Considering we use continuous values for characterizing our land cover classes, linear regression is the appropriate technique for the analysis of the relevant factors as well as their quantitative relationships with each land cover (Lesschen et al. 2005). We apply a statistical analysis using the statistical software RStudio (RStudio 2021). An initial exploratory statistical analysis shows that some of the relationships between potential explanatory variables and the regenerated forest cover in 2011 are not linear. We apply a logarithmic transformation to the land use variables and to some explanatory variables. We also perform a correlation analysis between the variables in our data set to prevent those factors with a correlation coefficient to be used in the same regression (Table SM.4). Following the process adopted in Aguiar et al. (2007), after removing the explanatory variables that are strongly correlated (> 0.80) (Hill 1999), alternative linear models are constructed for finding the regression model with the significant variables $(p<0.05)$, the highest coefficient of multiple determination $\left(R^{2}\right)$, and the lowest Akaike information criteria (AIC). These parameters indicate the model with the best goodness of fit (Anselin et al. 2006). The regression coefficients (beta) are then standardized for determining the relative importance between the variables in the model (Aguiar et al. 2007). An automatic linear forward stepwise regression is applied to refine the models and discard nonsignificant variables.

To better understand the multiple factors underlying the natural regeneration process in the region, we build and compare four alternative linear regression models considering (a) only biophysical factors (B model); (b) biophysical and forest cover (Eco model); (c) biophysical, forest and other land covers (BH model); (d) biophysical, forest and other land covers; and (e) socioeconomic factors (BHS model). 
Table 2 Summary of previous studies

\begin{tabular}{|c|c|c|c|}
\hline Author & $\begin{array}{l}\text { Approach to identify the natural } \\
\text { regeneration potential }\end{array}$ & $\begin{array}{l}\text { Scale } \\
\text { Extension/resolution/ } \\
\text { temporal }\end{array}$ & Most important drivers/results \\
\hline $\begin{array}{l}\text { Schulz and } \\
\text { Schroder } \\
(2017)\end{array}$ & $\begin{array}{l}\text { Multiple logistic regression } \\
\text { models }\end{array}$ & $\begin{array}{l}\text { Central Chile/ } 1000 \mathrm{~m} \\
\text { and } / 26 \text { years }\end{array}$ & $\begin{array}{l}\text { The most important drivers are elevation, slope, precipitation in the } \\
\text { coldest quarter, temperature seasonality, and distance to primary } \\
\text { road. Regeneration potential occurs more clearly on the higher } \\
\text { mountain ranges, and only small areas show slightly higher } \\
\text { probabilities }\end{array}$ \\
\hline $\begin{array}{l}\text { Vergarechea } \\
\text { et al. } \\
\text { (2019) }\end{array}$ & Maximization of a likelihood & $\begin{array}{l}\text { Northern Plateau of } \\
\text { Spain/2ha/15 years }\end{array}$ & $\begin{array}{l}\text { The results also point to the existence of climate-mediated annual re- } \\
\text { generation occurrence, reflecting the complex interaction which ex- } \\
\text { ists between environmental factors and the optimum conditions for } \\
\text { natural regeneration }\end{array}$ \\
\hline $\begin{array}{l}\text { Strassburg } \\
\quad \text { et al. } \\
\quad(2018)\end{array}$ & $\begin{array}{l}\text { Ecological uncertainty of forest } \\
\text { restoration success for plant } \\
\text { biodiversity }\end{array}$ & $\begin{array}{l}\text { Atlantic Forest Biome/1 } \\
\qquad \mathrm{km} / \text { - }\end{array}$ & $\begin{array}{l}\text { The study identifies areas where natural regeneration and/or active res- } \\
\text { toration methods are most likely to foster plant biodiversity recovery } \\
\text { to similar levels found in reference systems }\end{array}$ \\
\hline $\begin{array}{l}\text { Crouzeilles } \\
\text { et al. } \\
(2020)\end{array}$ & Random forest regression models & $\begin{array}{l}\text { Atlantic Forest } \\
\text { Biome/municipality } \\
\text { and } 30 \mathrm{~m} / 20 \text { years }\end{array}$ & $\begin{array}{l}\text { Predictive model based on } 10 \text { variables related to landscape conditions, } \\
\text { soil properties, climate, topographic relief, and past disturbance } \\
\text { intensity related to pasture and sugarcane production explain } 80.2 \% \\
\text { of the natural regeneration at municipality resolution. The most } \\
\text { important predictor of the occurrence of natural regeneration is the } \\
\text { proximity to forest at the pixel-based resolution }\end{array}$ \\
\hline $\begin{array}{l}\text { Carvalho } \\
\text { Ribeiro } \\
\text { et al. } \\
\text { (2020) }\end{array}$ & $\begin{array}{l}\text { Favorability-to-natural } \\
\text { regeneration model }\end{array}$ & Rio Doce basin $/ 30 \mathrm{~m} /$ - & $\begin{array}{l}\text { The study takes into account the (1) landscape context (land use and } \\
\text { legal compliance), (2) physiographic attributes related to local resil- } \\
\text { ience (as concave terrain), and (3) land use intensity }\end{array}$ \\
\hline $\begin{array}{l}\text { Molin et al. } \\
\quad(2018)\end{array}$ & $\begin{array}{l}\text { Transition matrices and weight of } \\
\text { evidence coefficients }\end{array}$ & $\begin{array}{l}\text { Piracicaba River } \\
\text { basin } / 30 \mathrm{~m} / 10 \text { years }\end{array}$ & $\begin{array}{l}\text { The authors evaluate } 12 \text { variables used to model the spatial probability } \\
\text { of natural regeneration (biophysical variables: soil type, } \\
\text { hydrographic network, forest type, rainfall, slope, and altitude; } \\
\text { socioeconomic variables: population density, rural population } \\
\text { density, municipal GDP, road network, urban spots, and predominant } \\
\text { land uses). Among the } 12 \text { variables used, the six socioeconomic } \\
\text { variables show negligible weights of evidence. Slope, distance to } \\
\text { watercourses, and distance to forest remnants are the main } \\
\text { biophysical drivers of forest regeneration in the basin }\end{array}$ \\
\hline $\begin{array}{l}\text { Pandovezi } \\
\quad \text { et al. } \\
\text { (2018) }\end{array}$ & Logistic regression model & Paraiba Valley/30m/ - & $\begin{array}{l}\text { The authors evaluate five biophysical variables (distance to remnant } \\
\text { forest, elevation, slope, aspect, and curvature) that are relevant } \\
\text { ecological processes. Among the variables, the most relevant is the } \\
\text { distance to remnant forest }\end{array}$ \\
\hline $\begin{array}{l}\text { Silva et al. } \\
\text { (2016a) }\end{array}$ & $\begin{array}{l}\text { Multi-layer Perception by Neural } \\
\text { Network }\end{array}$ & $\begin{array}{l}\text { Paraiba } \\
\text { Valley/municipalit- } \\
\text { y/26 years }\end{array}$ & $\begin{array}{l}\text { The authors evaluate } 17 \text { variables for three periods (1985-1995; } \\
\text { 1995-2005; and 2005-2011); the proximity of forest plays a major } \\
\text { role in the increase of forest cover in all periods. The first period of } \\
\text { the analysis reveals that biophysical drivers (aspect and slope) are the } \\
\text { most relevant drivers. For the next periods of change, a different set } \\
\text { of socioeconomic variables (proximity of eucalyptus, rural farms, } \\
\text { credit farms, and concentrate of industries and commercial estab- } \\
\text { lishments) are more relevant for the forest increase }\end{array}$ \\
\hline
\end{tabular}

\section{LuccME modeling approach}

LuccME is an open-source framework for the development of dynamic spatially explicit land change models (LCM) representing the evolution of land use and cover spatial patterns over time. The LuccME framework organizes the models in three components, following the generic structure found in land use and cover change models (Verburg et al. 2006). A demand component defines the amount of change that will be allocated by the model at each time step. A potential component, usually based on empirical methods, calculates the potential for each land cover in each cell, according to a set of explanatory variables. The allocation component is the core computational mechanism that distributes, at each time step, the changes as defined by the demand according to the potential of each cell. LuccME framework provides multiple components which can be chosen according to the study area and land change process needs. 
In this work, we use the LuccME components based on the Conversion of Land Use and its Effects (CLUE) model for continuous land use variables (Veldkamp and Fresco 1996; Verburg et al. 1999) to generate our natural regeneration alternative scenarios for 2025. The CLUE model projects near future land use changes based upon current and past land use conditions, and has been applied to many different countries and scales to understand the evolution of land use and cover spatial patterns over time for continuous land use variables (e.g., Aguiar et al. 2016).

In our work, the dynamic land cover variables are the percentage of regenerated forest and percentage of pasture in each cell of $1 \mathrm{~km} \times 1 \mathrm{~km}$. As our core interest is the conversion from pasture to forest, we adopt the simplifying assumption that the other land use classes remain static during the calibration and scenarios phase. We also assume that the remnant forests will not be disturbed. We calibrate our potential component using the alternative linear regression models described in the "Exploratory analysis and selection of alternative statistical models" section. In this case, the potential for each dynamic class in each cell is computed at each time step using the coefficients of the linear regression models estimated for each class. The potential is the difference between the current land cover percentage and the estimated percentage according to the linear regression models (Verburg et al. 1999). At each time step, we estimate a natural regeneration potential for each cell (and a pasture potential). We then run the allocation simulation until 2015, validating the results against the observed 2015 information (also derived from Silva et al. 2016a and Ronquim et al. 2016). We use a multiscale validation metric (Van Vliet et al. 2016) to support the choice/analysis of alternative models capturing the change from 2011 to 2015. Finally, we run scenarios from 2015 to 2025, as described in the "Scenarios: alternative assumptions about the scale restoration commitments" section.

\section{Scenarios: alternative assumptions about the scale restoration commitments}

We explore three alternative scenarios related to different restoration commitments targeting our study area, comparing their cost-effectiveness (see the "Indicators for comparing the scenarios: cost, carbon, biodiversity and soil" section for a description of the cost, soil, biodiversity, and carbon indicators considered), according to the following assumptions. During the previous decade (2005-2015), the rate of increase of the natural regeneration cover has been, in average, $60 \mathrm{~km}^{2} /$ year (Table 1). We assume this rate will be maintained in the next decade (2015-2025), as the contribution of the region to the Atlantic Forest Restoration Pact (that is an additional $600 \mathrm{~km}^{2}$ in 10 years). We also assume the maintenance of the same conditions and relations captured by the statistical models derived for 2011. Applying the empirically derived relationships relating patterns of land cover to explanatory factors is acceptable for such time frame (Verburg et al. 2004). For regenerated forest, we opt for using the Eco model to run the scenarios. This model better aligns with our overall goal of favoring passive ecological restoration, minimizing costs related to the active method. For pasture, we use a model combining biophysical, land cover, and socioeconomic variables (BHS model).

The three scenarios vary in relation to the priority area defined by the different commitments:

- Unconstrained scenario (Atlantic Forest Restoration Pact): Allocation is possible in the pasture area of the whole study area.

- Constrained scenario 1 (Protection PSA Program): Allocation is restricted to areas of high priority for the Protection PSA Program, that is, areas for high gain in biodiversity conservation, climate change, and water supply.

- Constrained scenario 2 (Hydric PSA Program): Allocation restricted to 34 watersheds inside our study area, which are relevant for the Hydric PSA Program, that focus on water supply.

Therefore, in each scenario, we work with alternative spatial partitions which might not constrain the possible area of conversion from pasture to regenerated forest (Fig. 3). The first scenario allows converting pasture into regenerated forest in the whole study area, without constraints or alignment to the state-level programs. This scenario aligns to the Atlantic Forest Restoration Pact (Pact) that aims to restore 15 Mha of degraded lands in the Brazilian Atlantic Forest Biome by 2050 (Calmon et al. 2011), where our study area is located. The second scenario only allows allocating regenerated forest in the pasture area in areas of high priority for gains in biodiversity conservation, climate change, and water supply according to the Protection PSA Program (Fig. 3b) (SÃO PAULO 2017, 2019). The last scenario constrains the allocation of regenerated forest in the remaining pasture area of the 34 watersheds considered a priority study area for gains in water supply as defined by the Hydric PSA Program (OIKOS 2015) (Fig. 3c).

The spatial partitions considered in the different scenarios contain 5453,1650 , and $1688 \mathrm{~km}^{2}$ of available pasture land, respectively, as illustrated in Fig. 3. Although with some small differences, the Hydric PSA Program (OIKOS 2015) is nested to the Protection PSA Program area (SÃO PAULO 2019). Both of them are nested to the area of the unconstrained scenario.

\section{Indicators for comparing the scenarios: cost, carbon, biodiversity, and soil}

The indicators used to compare each scenario are computed as follows (see details in Supplementary Material): 
Spatial partitions of the alternative scenarios

a) Unconstrained Scenario

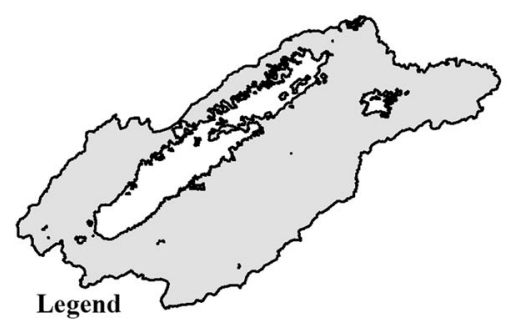

Atlantic Forest

Whole study area

High priority area for the Protection PSA Program

Priority areas for the Hydric PSA Program b) Constrained Scenario 1

c) Constrained Scenario 2
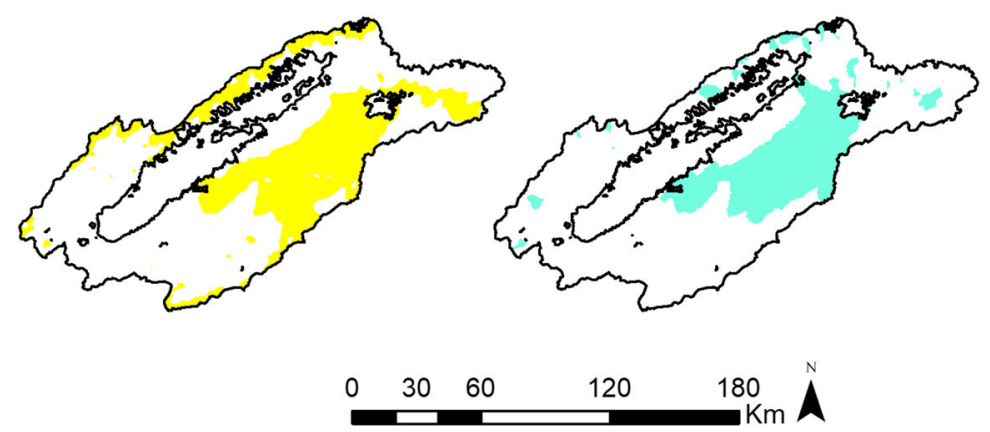

Sirgas 2000 - UTM 23S

Fig. 3 Spatial partitions considered in A unconstrained scenario; B constrained scenario 1: high priority areas for the Protection PSA Program; and C constrained scenario 2: priority areas for the Hydric PSA Program

- Cost of restoration (US\$): For each scenario, we compare the costs of restoration that is a sum of costs of allocating passive and active restoration across cells. We use the values presented by Brancalion et al. (2019) to assign per hectare costs for natural and active restoration methods. Next, we use the regenerated forest percentage estimated in the Eco model as the maximum biophysical capacity (MBC) to forest regrowth. The $\mathrm{MBC}$ is used to identify a per cell threshold that will define if the amount of natural restoration a cell can support. We assume that any additional restoration that surpasses this cap value will require an active restoration method (Fig. SM.4). The total cost of restoration is the sum of the cost of restoration of each cell.

- Biodiversity benefit (average number of benefited groups or species/ha): For each scenario, this indicator is the average number of benefited groups or species by restoration actions in the regenerated forest area from 2015 to 2025 . The number of benefited groups or species by restoration actions is derived from the score of priority areas for biodiversity restoration proposed by Joly et al. (2010) (Fig. SM.6) that ranges from 0 (no priority) to 8 (high priority). For each cell, the number of benefited groups or species by restoration actions is the majority score. The majority score of the cell is multiplied by the regenerated forest incremented area from 2015 to 2025 of the cell. The majority score of the scenario is the sum of this multiplication of each cell. The biodiversity gain is the division of the majority score of the scenario by the total forest incremented area from 2015 to 2025 .

- Carbon benefit (ton): For each scenario, the indicator represents the total carbon stock increase from the conversion from pasture to regenerated forest area from 2015 to 2025 . For each cell, we quantify the mean carbon stock increase (ton/ha) based on the carbon stock adopted in the Third
Brazilian Inventory of greenhouse gas emissions to the UNFCCC (MCTI 2015). The mean carbon stock increase is multiplied by the regenerated forest incremented area from 2015 to 2025 of the cell. The carbon gain is the sum of this multiplication of each cell.

- Soil benefit (ton): For each scenario, the indicator represents the total reduction of soil loss with the conversion from pasture to regenerated forest area from 2015 to 2025 . For each cell, we quantify the mean reduction of soil loss [ton/ha/year] through the Universal Soil Loss Equation (USLE) based on Pandovezi et al. (2018). The mean reduction of soil loss [ton/ha/year] is multiplied by the restored forest incremented area from 2015 to 2025 of the cell. The soil gain is the sum of this multiplication of each cell.

\section{Results}

\section{Statistical analysis results}

In this section, we present the results of alternative linear regression models relating the regenerated forest cover in 2011 to alternative sets of candidate explanatory variables. The models are built by adding new groups of explanatory variables ("Explanatory factors related to natural regeneration spatial patterns" section). Some variables in these groups are found to be significant $(p<0.05)$ in some of the models and non-significant in others. Table 3 summarizes the final set of variables, in which models were included.

The B model (biophysical variables only) explains $37 \%$ of the variation of natural regeneration in the study according to $R^{2}$. The most important factors in this model relate the higher percentage of natural regeneration to the steep slopes with a 


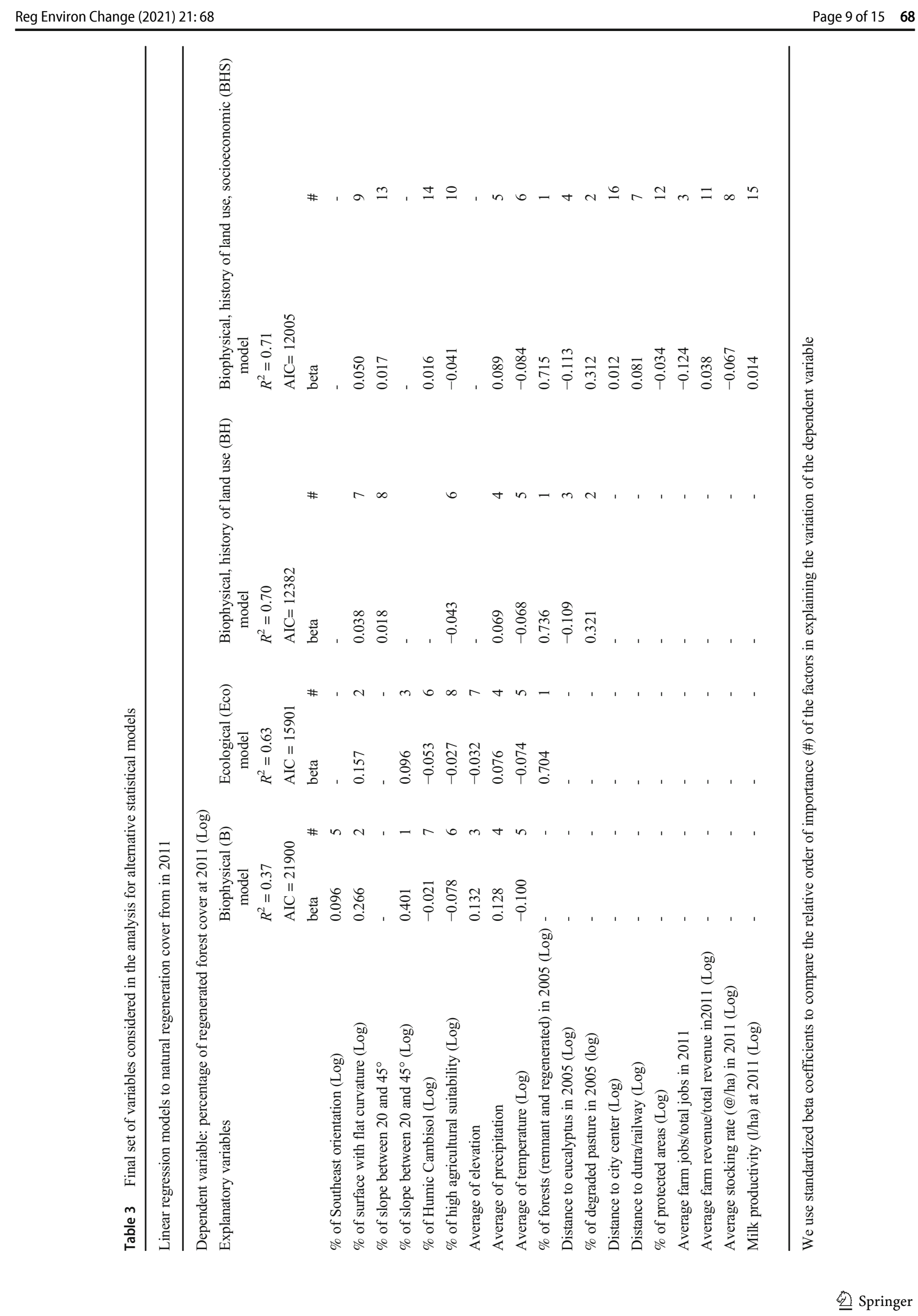


flat curvature, in elevated areas with higher precipitation (see Table 2). Terrain characteristics, climate, and agricultural suitability are significant factors in all models. However, adding the percentage of forests (remnant and regenerated) improves to $63 \%$ the explanatory power of the model (we name this combination of biophysical factors and percentage of forests as Eco model).

Including additional land cover factors ( $\mathrm{BH}$ model) increases the $R^{2}$ considerably $\left(R^{2}=0.70, \mathrm{AIC}=12,382\right)$. The significant factors included in the model relate to the percentage of degraded pasture in the cells in the previous years. It also relates distance from planted forests to natural regeneration. These factors remain as the most important ones when socioeconomic factors are included (BHS model).

Although adding several socioeconomic potential explanatory factors does not increase the explanatory power of the regression $\left(R^{2}=0.71, \mathrm{AIC}=12,005\right)$, some relevant understanding can be derived from this model. First, the percentage of jobs in rural areas in relation to the total number of jobs in the municipalities becomes the third more important variable in the model. It presents a negative signal, meaning that less jobs in the rural areas in a given municipality implies more natural regeneration in the cells in such municipalities. Aligned to that, the furthest to the main highway (parallel and close to the railway, where most of the large cities and industries are located), the higher the percentage of natural regeneration. Also interestingly, higher stocking rates implies small percentages of natural regeneration within the cell. On the other hand, milk productivity presented a positive signal.

\section{Maximum biophysical capacity}

Using the Eco model (Table 2), we estimate the spatial distribution of the maximum biophysical capacity $(M B C)$, illustrated in Fig. 4. The MBC values are used to compute the cost of restoration in each scenario (Atlantic Forest Restoration Pact, Protection PSA Program, and Hydric PSA Program). And the cost of restoration in each scenario is used to compare the cost of all scenarios.

As Fig. 4 illustrates, the MBC varies from 0 to 0.50 in the study area. $\mathrm{MBC}$ values indicate the proportion of the cell area that can support natural regeneration and the allocation of restoration above this biophysical threshold would require active restoration methods, e.g., for cells with $0.3 \mathrm{MBC}$ for which the allocation of regeneration in a given scenario equals to a proportion of 0.4 of the cell area, 0.3 would be allocated as natural restoration, and the remainder 0.1 as active restoration. The MBC average is close to 0.1 (see the histogram in Fig. SM.4), and around $60 \%$ of the cells in the region have less than $10 \%$ of maximum biophysical capacity for natural regeneration. This impacts the costs of our scenarios, as discussed in the next section.

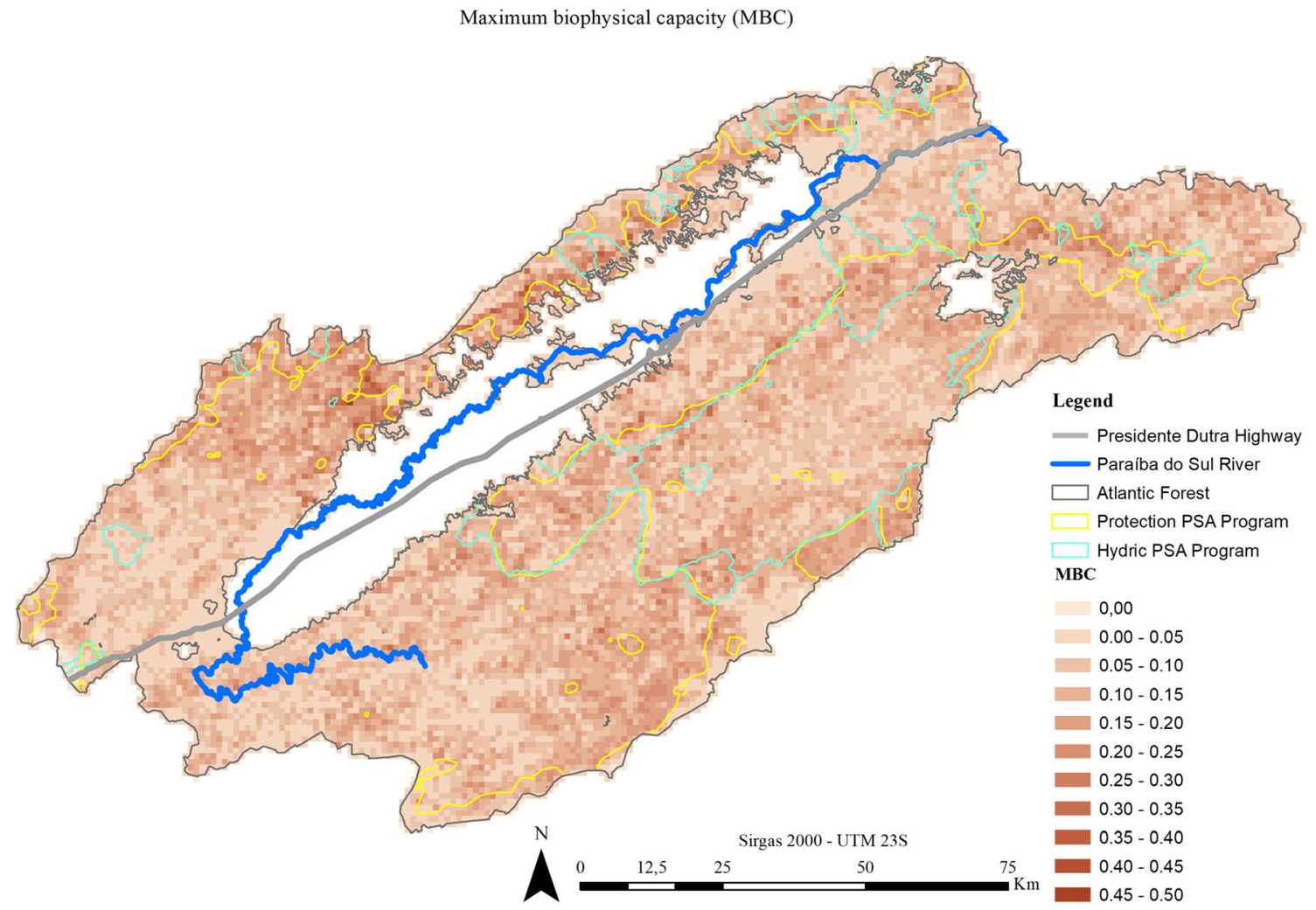

Fig. 4 Spatial distribution of the maximum biophysical capacity (MBC) estimated using the Eco model (linear regression) 


\section{Alternative allocation scenarios}

Based on the results of the statistical analysis phase ("Statistical analysis results" section), in this section, we present the LuccME modeling and scenario results. We parameterize, calibrate, and validate LuccME (from 2011 to 2015) with the alternative linear regression models for regenerated forest, as Table SM.9 summarizes. Interestingly, this model combination (Ecological for Regeneration and BHS for Pasture) provides slightly better results in the LuccME multiscale validation process from 2011 to 2015 (Table SM.10). Combining the two models allows the LuccME allocation component to explore the competition in each cell between the multiple factors underlying the pasture economic activity and the ecological processes allowing for regeneration.

Figure 5 illustrates the alternative spatial patterns of change in forest cover from 2015 to 2025 under the assumptions of the three alternative scenarios ("Scenarios: alternative assumptions about the scale restoration commitments" section). Given the smaller target area in the two programs (Fig. 5b and c), the percentage of change in each cell is comparatively higher than in the unconstrained scenario (Fig. 5a). The final forest cover considering existing and newly allocated areas is shown in Fig. 5d, e, and f. Table 4 compares the results of the three scenarios considering the indicators of cost, biodiversity, soil, and carbon.

Table 4 shows the comparison of the carbon, biodiversity, and soil indicators across the scenarios. Each scenario has positive and negative aspects in relation to each other. Although the Protected PSA and Hydric PSA Scenarios outperformed the unconstrained scenario in relation to the soil and carbon indicators, they present relatively worse biodiversity gain indicators, with a slight decrease in the average number of benefited groups or species. However, all scenarios have a similar number of benefited groups or species, close to three, the dominant category in the study area. On the other hand, the Protection PSA presents a $10 \%$ improvement in the soil indicators when compared to the Hydric PSA scenario. The results for carbon are similar.

We observe the enforcement of conversion from pasture to forest within cells with lower natural regeneration potential in

\section{Total regenerated forest incremented in 2015-2025 (Inc2025) and Total forest in 2025 (Tot2025)}

a) Unconstrained Scenario - Inc2025

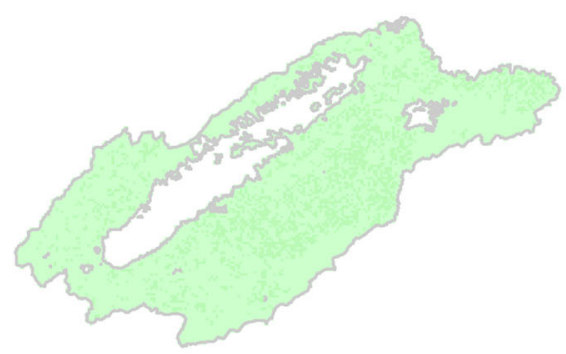

d) Unconstrained Scenario - Tot2025

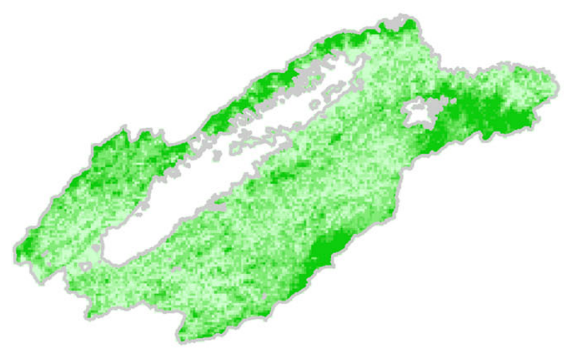

Legend

Atlantic Forest

Whole study area

High priority area for the Protection PSA Program

Priority areas for the Hydric PSA Program b) Constrained Scenario 1 - Inc2025

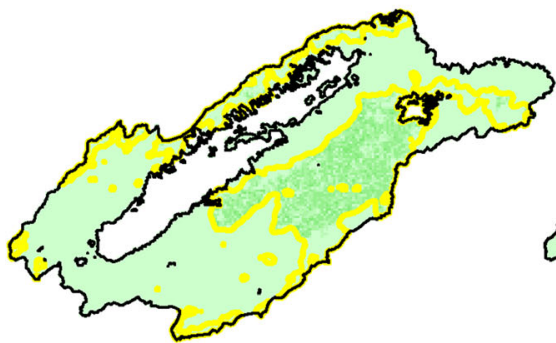

e) Constrained Scenario 1 - Tot2025
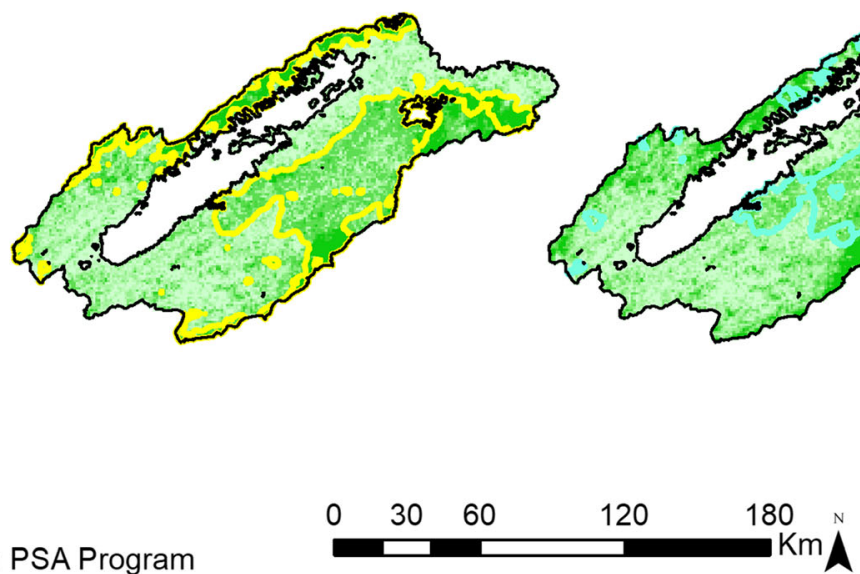

Sirgas 2000 - UTM 23S c) Constrained Scenario 2 - Inc2025

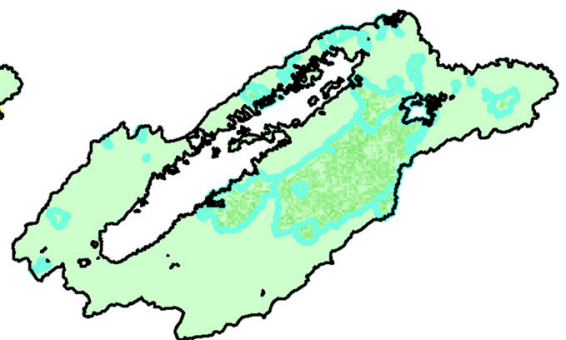

f) Constrained Scenario 2 - Tot2025

Fig. 5 Scenario results, where the $600 \mathrm{~km}^{2}$ of regenerated forest were allocated under the scenarios 
Table 4 Scenario comparison: cost-effectiveness (2015-2025) of converting $600 \mathrm{~km}^{2}$ from pasture to regenerated forest (Eco model)

\begin{tabular}{llll}
\hline Constrained scenarios & & & \\
\hline Indicator & $\begin{array}{l}\text { Unconstrained scenario (whole } \\
\text { area) }\end{array}$ & $\begin{array}{l}\text { High priority areas-PSA } \\
\text { Protection }\end{array}$ & $\begin{array}{l}\text { Priority areas-PSA } \\
\text { Hydric }\end{array}$ \\
\hline Cost of restoration (million US\$) & 130.65 & 134.41 & 133.61 \\
Carbon Gain (M TonC) & 4.45 & 4.50 & 4.51 \\
Soil Gain (M Ton) & 1.82 & 2.20 & 2.03 \\
$\begin{array}{l}\text { Biodiversity gain (average number of benefited groups or } \\
\text { species/ha) }\end{array}$ & 3.01 & 2.96 & 2.78 \\
\hline
\end{tabular}

the constrained scenarios (Protection PSA Program and Hydric PSA Program) in comparison to the natural regeneration potential of the unconstrained scenario. This conversion within cells with lower natural regeneration potential results from the prohibition to allocate new forest areas outside the spatial partition of the constrained scenarios - excluding cells that could potentially have higher natural regeneration potential. The enforced conversion from pasture to forest within cells with lower potential increases the total cost in both scenarios (Fig. 4). In cells with lower potential, it is necessary to use an active (and more expensive) method for restoring the incremented area, which increases the restoration cost. Besides, as we observe in Fig. 4, given the smaller target areas in the two programs, the percentage of change in the available cells is comparatively higher to allocate the $600 \mathrm{~km}^{2}$ of forest. Changes in the unconstrained scenario are, as expected, more spread, i.e., less concentrated in each cell.

\section{Discussion}

\section{Relevant factors to the natural regeneration process}

Independently of the spatial and temporal scales, and methods used, previous studies identify the importance of combining multiple drivers for understanding the natural regeneration potential (Table 2). Our work builds on the previous studies that analyzed the underlying factors related to natural regeneration by building models that combine biophysical, land use history, and socioeconomic data in alternative ways.

As Schulz and Schroder (2017) concluded in Central Chile, the main significant biophysical factors explaining forest regeneration in this work are local terrain characteristics. Local terrain characteristics remain significant even when other land cover and socioeconomic variables are added. Carvalho Ribeiro et al. (2020) presuppose that concave areas have local terrain characteristics that favor natural regeneration because they accumulate soil and water. However, our model identified that flat areas are more relevant for natural regeneration. Flat areas are more stable environments, resulting in less movement of soil and water in relation to concave areas.
This stability promotes the establishment of propagules during the natural regeneration processes (Santos et al. 2016).

South facing terrain is another relevant factor for forest growth as they receive less solar radiation (Silva et al. 2016a). One possible explanation is that Atlantic Forest species are adapted for shading and prevail in low light conditions (Mendes et al. 2019). Interestingly, the south facing factor is not significant when the forest cover is included (Eco model).

Adding the forest cover variable greatly improves the explanatory power of the statistical model when compared to the biophysical factors only. The results of the Eco model corroborate the findings of Carvalho Ribeiro et al. (2020) that forest fragments are important sources of seeds for nearby areas in natural regeneration processes. Our approach for estimating costs was solely based on the biophysical capacity for undergoing ecological regeneration at the cell level, which provides a straightforward indicator for the necessity of applying active restoration methods, as opposed to previous work (Crouzeilles et al. 2020) that included socioeconomic drivers when calculating the suitability for natural regeneration and assigning associated costs.

Our statistical analysis also explores the relative importance of other land cover and socioeconomic factors. A key land cover factor in the model is the percentage of degraded pasture, as replacing them by forests that previously occupied the area is a well-known process in the region (Chazdon et al. 2020). In fact, our land cover change data source shows that 74\% of the new forest areas between 1985 and 2011 take place over degraded pasture in Paraiba Valley (Silva et al. 2016a).

We also explore how different categories of socioeconomic factors could improve the statistical models. Although presenting a marginal increase in the explanatory power, the BHS model sheds light on how the socioeconomic heterogeneity of the region relates to the natural regeneration spatial patterns, corroborating previous results that indicate socioeconomic drivers play an important role in forest recovery (Silva et al. 2016a). The percentage of jobs in rural areas and the distance to the major highway, where the large cities and industries are located (Fig. 1), are particularly important. In the borders of Paraiba Valley, there is an interesting combination of adequate biophysical and socioeconomic conditions 
for regeneration, as they are far away from the most economically active areas in the region. Interestingly, the percentage of regenerated forest in the cells also presents a positive relation to both farm revenue and cattle stocking rate in the BHS model. These results need to be further explored, as they might provide links to the land sparing debate (Loconto et al. 2020). These results might also imply that multiple pathways of forest transition (Rudel et al. 2005; Rudel et al. 2020) are taking place in the region, driven by the abandonment of degraded pastures in some cases, but potentially by agricultural intensification in others..

\section{Planning the implementation of restoration commitments}

The results of our analysis also indicate that there is no "better" solution among the scenarios we explore. Nesting local to large-scale commitments (like in scenario 2) might provide a compromised solution. Our results reinforce the importance of the simultaneous planning of large-scale and local restoration commitments, and the relevance of multiscale approaches (Adams et al. 2016).

Paraiba Valley accumulates $2639 \mathrm{~km}^{2}$ of natural regeneration forests from 1985 to 2015 (Table 1), mainly converted from pasture areas. Although there is still a large amount of pasture in the region $\left(5453 \mathrm{~km}^{2}\right.$ ), our results suggest that such areas have low ecological potential for natural regeneration. Using the available data for 2011, calibrated for 2015, our models indicate that the natural regeneration potential of the region is actually very low, as the estimated MBC (maximum biophysical capacity) varies from 0 to 0.50 in the study area. This incurs in high restoration costs across scenarios, reinforcing the need to further investigate the feasibility of large-scale forest restoration goals based on the natural regeneration potential (Lewis et al. 2019). This is particularly true in areas in which the historical anthropogenic degradation can impact ecosystem structure and functioning (Rocha et al. 2015).

\section{Limitations and suggestions for future studies}

One missing aspect in the ecological model is possibly the inclusion of an indicator of soil degradation/loss as a potential candidate to explain the low natural regeneration potential (or $\mathrm{MBC}$ ) we estimated in our study. Soil degradation/loss reflects the land use history and inadequate agricultural practices (Medeiros et al. 2016), which are very common in this region that have undergone different cycles of agricultural production since the nineteenth century (Silva et al. 2017). Although other studies have also identified a low regeneration potential for the Paraiba Valley (Pandovezi et al. 2018), we suggest that future studies could evaluate our estimated MBC by comparing it with field data. Zheng et al. (2021) and Vergarechea et al. (2019) use the observed data for calibrating models that are looking for estimating the regeneration potential.

Furthermore, in future studies, we envision some possible improvements. For example, scenarios could include land restrictions such as forcing new regeneration areas to be evenly distributed across the 34 basins in the hydric scenario. Such restrictions could also address especifities of the legal environmental framework in Brazil, in particular the Forest Code (Sparovek et al. 2019). Another aspect not considered in our analysis is the transaction costs, for example, the cost of negotiating with farmers and monitoring the implementation of a PSA program. It could possibly be higher in the unconstrained scenario, reflecting the less concentrated effort. Another possible improvement is the use of fine resolution data for estimating the biodiversity and the gains.

The current version of LuccME model does not account for the competition for pasture land with other uses, such as eucalyptus. Finally, and importantly, the explanatory variables in our model are currently not dynamic. This is particularly relevant for distance to forest areas, especially, because remnant forests are decreasing over time (Table 1). Future works could consider dynamically updating such variables, in particular the changes in forest areas produced by the model itself. This might increase the maximum biophysical capacity $(M B C)$ of the landscape to forest growth, and consequently the local need for active methods.

\section{Conclusion}

The implementation of large-scale restoration commitments is a key challenge of our times. Our study builds upon the extensive literature about forest restoration and proposes a novel approach to support the planning of multiple restoration goals and programs targeting the same area. We combine statistical analysis and spatially explicit dynamic modeling to assess the cost-effectiveness of alternative allocation models. The LuccME allocation mechanism distributes the necessary change through the scenario target area proportionally to their potential for natural regeneration. We believe our approach can positively contribute to improving forest restoration commitments. Programs for payment for ecosystem services, for example, could use our results for selecting the farms that are most indicated for receiving payment for passive restoration. We also believe our approach can be used to support largescale decision-making about the overall design of alternative plans and combined to other approaches for more refined analysis (e.g., optimization models).

Supplementary Information The online version contains supplementary material available at https://doi.org/10.1007/s10113-021-01792-0. 
Funding This work was supported by the Coordination of Improvement of Higher Level Personnel of Brazil (in Portuguese Coordenação de Aperfeiçoamento de Pessoal de Nível Superior, CAPES). This work was partially funded by grant \#2017/22269-2, São Paulo Research Foundation (FAPESP). Financial assistance to R.R.R. from the FAPESP (2013/507185). Thanks to Marcelo Matsumoto for running the Universal Soil Loss Equation (USLE) in InVEST Sediment Delivery Ratio (SDR) model for us. Thanks to Gilney Bezerra for the help in developing the statistical model. Special thanks to the actors of the Restoration Forestry of the Paraíba Valley.

Open Access This article is licensed under a Creative Commons Attribution 4.0 International License, which permits use, sharing, adaptation, distribution and reproduction in any medium or format, as long as you give appropriate credit to the original author(s) and the source, provide a link to the Creative Commons licence, and indicate if changes were made. The images or other third party material in this article are included in the article's Creative Commons licence, unless indicated otherwise in a credit line to the material. If material is not included in the article's Creative Commons licence and your intended use is not permitted by statutory regulation or exceeds the permitted use, you will need to obtain permission directly from the copyright holder. To view a copy of this licence, visit http://creativecommons.org/licenses/by/4.0/.

\section{References}

Adams C, Rodrigues ST, Calmon M, Kumar C (2016) Impacts of largescale forest restoration on socioeconomic status and local livelihoods: What we know and do not know. Biotropica 48:731-744. https://doi.org/10.1111/btp.12385

Aguiar APD, Câmara G, Escada MIS (2007) Spatial statistical analysis of land-use determinants in the Brazilian Amazonia: Exploring intraregional heterogeneity. Ecol Model 209(2-4):169-188. https://doi. org/10.1016/j.ecolmodel.2007.06.019

Aguiar APD, Vieira ICG, Assis TO, Dalla-Nora EL, de Toledo PM et al (2016) Land use change emission scenarios: anticipating a forest transition process in the Brazilian Amazon. Glob Chang Biol 22: 1821-1840. https://doi.org/10.1111/gcb.13134

Anselin L, Syabri I, Kho Y (2006) GeoDa: an introduction to spatial data analysis. Geogr Anal 38(1):5-22. https://doi.org/10.1111/j.00167363.2005.00671.x

Boillat S, Scarpa FM, Robson JP, Gasparri I, Aide TM et al (2017) Land system science in Latin America: challenges and perspectives. Curr Opin Environ Sustain 26-27:37-46. https://doi.org/10.1016/j.cosust. 2017.01.015

Brancalion PHS, Meli P, Tymus JRC, Lenti FEB, Benini RM et al (2019) What makes ecosystem restoration expensive? A systematic cost assessment of projects in Brazil. Biol Conserv 240. https://doi.org/ 10.1016/j.biocon.2019.108274

Calmon M, Brancalion PHS, Paese A, Aronson J, Castro P et al (2011) Emerging Threats and Opportunities for Large-Scale Ecological Restoration in the Atlantic Forest of Brazil. Restor Ecol 19(2): 154-158. https://doi.org/10.1111/j.1526-100X.2011.00772.x

Carneiro TGS, Andrade PR, Câmara G, Monteiro AMV, Pereira RR (2013) An extensible toolbox for modeling nature-society interactions. Environ Model Softw 46:104-117. https://doi.org/10.1016/j. envsoft.2013.03.002

Carvalho Ribeiro SM, Rajão R, Nunes F, Assis D, Ambrósio Neto J et al (2020) A spatially explicit index for mapping Forest Restoration
Vocation (FRV) at the landscape scale: Application in the Rio Doce basin, Brazil. Sci Total Environ. https://doi.org/10.1016/j. scitotenv.2020.140647

Chazdon RL, Lindenmayer D, Guariguata MR, Crouzeilles R, Benayas JMR et al (2020) Fostering natural forest regeneration on former agricultural land through economic and policy interventions. Environ Res Lett. https://doi.org/10.1088/1748-9326/ab79e6

Crouzeilles R, Santiami J, Rosa M, Pugliese L, Brancalion PHS et al (2019) There is hope for achieving ambitious Atlantic Forest restoration commitments. Perspect Ecol Conserv 17:80-83. https://doi. org/10.1016/j.pecon.2019.04.003

Crouzeilles R, Beyer HL, Monteiro LM, Feltran-Barbieri R, Pessôa ACM et al (2020) Achieving cost-effective landscape-scale forest restoration through targeted natural regeneration. Conserv Lett:e12709. https://doi.org/10.1111/conl.12709

Hill RC (1999) Econometria. Saraiva, São Paulo

IBGE (2012) Manual Técnico da Vegetação Brasileira. IBGE, Rio de Janeiro, p 2012 https://biblioteca.ibge.gov.br/visualizacao/livros/ liv63011.pdf. Accessed 13 May 2020

IPBES (2019) Global assessment report on biodiversity and ecosystem services of the Intergovernmental Science-Policy Platform on Biodiversity and Ecosystem Services. In: Brondizio ES, Settele J, Díaz S, Ngo HT (ed) IPBES secretariat, Bonn, Germany. https:// www.ipbes.net/global-assessment. Accessed 13 May 2020

Joly CA, Rodrigues RR, Metzger JP, Haddad CFB, Verdade LM et al (2010) Biodiversity Conservation Research, Training, and Policy in São Paulo. Science 328. https://doi.org/10.1126/science.1188639

Lesschen JP, Verburg PH, Staal SJ (2005) Land-Use and Land-Cover Change (LUCC) Project. IV. International Human Dimensions Programme on Global Environmental Change (IHDP) V. International Geosphere-Biosphere Programme (IGBP). International Livestock Research Institute, Nairobi, Kenya. http:// www.dpi.inpe.br/Miguel/GLP\%26LUCC_SeriesPubs/LUCC_No 7_StatisticalMethods_inLandUseAnalysis 2005.pdf. Accessed 19 Apr 2021

Lewis SS, Wheele CE, Mitchard ETA, Koch A (2019) Regenerated natural forests to store carbon. Nature 568(7750):25-28. https://doi.org/ 10.1038/d41586-019-01026-8

Loconto A, Desquilbet M, Moreau T, Couvet D, Dorin B (2020) The land sparing - land sharing controversy: Tracing the politics of knowledge. Land Use Policy 96. https://doi.org/10.1016/j.landusepol. 2018.09.014

MCTI (2015) Terceiro inventário brasileiro de emissões e remoções antrópicas de gases de efeito estufa, Relatórios de referência, Setor uso da terra, mudança do uso da terra e florestas. http://sirene.metic. gov.br/portal/opencms/publicacao/index.html. Accessed 12 May 2020

Medeiros GOR, Giarolla A, Sampaio G, Marinho MA (2016) Diagnosis of the Accelerated Soil Erosion in São Paulo State (Brazil) by the Soil Lifetime Index Methodology. Revista Brasielira de Ciência do Solo. https://doi.org/10.1590/18069657rbes20150498

Mendes CN, Diniz ES, Terra MCNS, Jeannot KK, Fontes MAL (2019) Light conditions imposed by canopy: allometric strategies of an understorey palm (geonoma schottiana mart.) in Atlantic Forest. J Trop For Sci 31(3):332-342. https://doi.org/10.26525/jtfs2019.31. 3.332

Molin PG, Chazdon R, Ferraz SFB, Brancalion PHS (2018) A landscape approach for cost-effective large-scale forest restoration. J Appl Ecol:1-12. https://doi.org/10.1111/1365-2664.13263

OIKOS (Instituto Oikos de Agroecologia) (2015) Programa de Pagamento por Serviços Ambientais para os Mananciais de Abastecimento Público do Trecho Paulista da Bacia do Paraíba do Sul. São Paulo. http://institutooikos.org.br/projetos/ DOCUMENTOFINALPSAAGUAVALEDOPARAIBA.pdf. Accessed 12 May 2020 
Pandovezi A, Oliveira M, Matsumoto M, Feltran-Barbieri R (2018) Oportunidades para restauração de paisagens e florestas na porção paulista do Vale do Paraíba: Plano de Desenvolvimento Florestal Territorial para a porção paulista do Vale do Paraíba /coordenação geral Aurélio Padovezi. - 1. ed. - Porto Alegre :Ideograf, https:// www.researchgate.net/publication/327041421 OPORTUNIDADES PARA RESTAURACAO DE PAISAGENS E FLORESTAS NA PORCAO PAULISTA DO_VALE_DO_PARAIBA. Accessed 12 May 2020

Rocha JHT, Santos AJM, Diogo FA, Backes C, Melo AGC et al (2015) Reforestation and Recovery of Soil Chemical and Physical Attributes. Floresta e Ambiente 22(3):299-306. https://doi.org/10. 1590/2179-8087.041613

Rodrigues RR, Gandolfi S, Nave AG, Aronson J, Barreto TE et al (2011) Large-scale ecological restoration of high-diversity tropical forests in SE Brazil. For Ecol Manag 261:1605-1613. https://doi.org/10. 1016/j.foreco.2010.07.005

Ronquim CC, Silva RFB, Figueiredo EB, Bordonal RO, Teixeira AHC et al (2016) Carbon sequestration to the land-use and land-cover changes in the forestry sector in Southern Brazil. Remote Sens Agric Ecosyst Hydrol XVIII:99981T. https://doi.org/10.1117/12. 2242094

Rossato DR, Hoffmann WA, Franco AC (2009) Stomatal traits of cerrado and gallery forest congeneric pairs growing in a transitional region in central Brazil. Acta Bot Bras 23(2):499-508. https://doi.org/10. 1590/S0102-33062009000200021

Rossi M (2017) Mapa pedológico do Estado de São Paulo: revisado e ampliado. São Paulo: Instituto Florestal. https://smastr16.blob.core. windows.net/iflorestal/2017/11/Livro_Solos1.pdf. Acesseed 12 May 2020

RStudio (2021) https://www.rstudio.com/products/rstudio/download/. Accessed 13 May 2020

Rudel TK, Coomesb OT, Moran E, Achardd F, Angelsene A et al (2005) Forest transitions: towards a global understanding of land use change. Glob Environ Chang 15:23-31. https://doi.org/10.1016/j. gloenvcha.2004.11.001

Rudel TK, Meyfroidt P, Chazdon R, Bongers F, Sloan S, Grau HR, Van Holt T, Schneider L (2020) Whither the forest transition? Climate change, policy responses, and redistributed forests in the twenty-first century. Ambio 49:74-84. https://doi.org/10.1007/s13280-01801143-0

Santos GL, Pereira MG, Lima SS, Ceddia MB, Mendonca VMM et al (2016) Landform curvature and its effect on the spatial variability of soil attributes, Pinheiral-RJ/BR. CERNE 22(4):431-438. https://doi. org $/ 10.1590 / 01047760201622042184$

SÃO PAULO 2017 Resolução SMA n 86/2017. Institui o Projeto de Pagamento por Serviços Ambientais para Proteção da Vegetação Nativa - PSA PROTEÇÃO, no âmbito do Projeto Clima e Biodiversidade na Mata Atlântica. https://smastr16.blob.core. windows.net/legislacao/2017/08/resolucao-sma-086-2017processo-5839-2017-institui-o-projeto-de-pagamento-por-servicosambientais-para-protecao-da-vegetacao-nativa.pdf. Accessed 20 Oct 2020

SÃO PAULO (2019) PROJETO CONEXÃO MATA ATLÂNTICA EM SÃO PAULO, Pagamento por Serviços Ambientais. https:// smastr16.blob.core.windows.net/home/2019/09/helena-carrascosadia-09.pdf. Accessed 20 Oct 2020

Scarano FR (2007) Rock outcrop vegetation in Brazil: a brief overview. Revista Brasil. Bot. 30(4):561-568. https://doi.org/10.1590/S010084042007000400002

Schulz JJ, Schroder B (2017) Identifying suitable multifunctional restoration areas for Forest Landscape Restoration in Central Chile. Ecosphere 8(1). https://doi.org/10.1002/ecs2.1644
Sewell A, van der Esch S, Löwenhardt H (2020) Goals and Commitments for the Restoration Decade: A global overview of countries' restoration commitments under the Rio Conventions and other pledges. PBL Netherlands Environmental Assessment Agency, The Hague https://www.pbl.nl/sites/default/files/downloads/pbl-2020-goalsand-commitments-for-the-restoration-decade-3906.pdf. Accessed 20 Oct 2020

Silva RFB, Batistella M, Moran EF (2016a) Drivers of land change: Human-environment interactions and the Atlantic forest transition in the Paraíba Valley, Brazil. Land Use Policy 58:133-144. https:// doi.org/10.1016/j.landusepol.2016.07.021

Silva RFB, Batistella M, Moran EF (2016b) Land Changes Fostering Atlantic Forest Transition in Brazil: Evidence from the Paraíba Valley. Prof Geogr:1-14. https://doi.org/10.1080/00330124.2016. 1178151

Silva RFB, Batistella M, Moran EF (2017) Socioeconomic changes and environmental policies as dimensions of regional land transitions in the Atlantic Forest, Brazil. Environ Sci Policy 74:14-22. https://doi. org/10.1016/j.envsci.2017.04.019

Sparovek G, Reydon BP, Pinto LFG, Faria V, Freitas FLM et al (2019) Who owns Brazilian lands? Land Use Policy 87. https://doi.org/10. 1016/j.landusepol.2019.104062

Strassburg BBN, Beyer HL, Crouzeilles R, Iribarrem A, Barros F (2018) Strategic approaches to restoring ecosystems can triple conservation gains and halve costs. Nat Ecol Evol. https://doi.org/10.1038/ s41559-018-0743-8

Van Vliet J, Bregt AK, Brown DG, van Delden H et al (2016) A review of current calibration and validation practices in land-change modeling. Environ Model Softw. https://doi.org/10.1016/j.envsoft.2016. 04.017

Veldkamp A, Fresco LO (1996) CLUE: a conceptual model to study the Conversion of Land Use and its Effects. Ecol Model 85:253-270. https://doi.org/10.1016/0304-3800(94)00151-0

Verburg PH, Koning GHJ, Kok K, Veldkamp A, Bouma J (1999) A spatial explicit allocation procedure for modelling the pattern of land use change based upon actual land use. Ecol Model 116(1):45-61. https://doi.org/10.1016/S0304-3800(98)00156-2

Verburg PH, Schot PP, Dijst MJ, Veldkamp A (2004) Land use change modelling: current practice and research priorities. GeoJournal 61: 309-324. https://doi.org/10.1007/s10708-004-4946-y

Verburg PH, Kok K, Pontius RG, Veldkamp A (2006) Modeling land-use and land-cover change. In: Lambin EF, Geist $\mathrm{H}$ (ed) Land-Use and Land-Cover Change. Springer, Berlin, Heidelberg, pp 117-135. https://doi.org/10.1007/3-540-32202-7_5

Vergarechea M, Calama R, Fortin M, Ríoa M (2019) Climate-mediated regeneration occurrence in Mediterranean pine forests: A modeling approach. For Ecol Manag 446:10-19. https://doi.org/10.1016/j. foreco.2019.05.023

Vickers LA, Fox TR, Loftis DL, Boucugnani DA (2011) Predicting Forest Regeneration in the Central Appalachians Using the REGEN Expert System. J Sustain For 30:790-822. https://doi.org/ 10.1080/10549811.2011.577400

Zheng C, Wen Z, Liu Y, Guo Q, Jiang Y, Ren H, Fan Y, Yang Y (2021) Integrating Habitat Suitability and the Near-Nature Restoration Priorities into Revegetation Plans Based on Potential Vegetation Distribution. Forests 12:218. https://doi.org/10.3390/f12020218

Publisher's note Springer Nature remains neutral with regard to jurisdictional claims in published maps and institutional affiliations. 